VeroNIKa DżATKOVÁ ${ }^{1}$

\title{
E-participation in the Decision-Making Process in Post-Communist Countries
}

\section{Introduction}

Every modern democratic system presupposes the existence of civil society which promotes development different forms of political participation. These days, the potential of active citizenship is supported by the massive development of various information and communication technologies (ICT) whose major impact is equally present in public administration.

In this context, representatives of civil society could, with the help of ICT, create a background for empowering political participation and civic activism with the aim to have an impact on the public policy actors and make decision-making processes more effectual.

In this aspect, the political-scientific and public policy dimension of participation are connected. From the former point of view, participation is related to direct democracy and a crisis of representative democracy. On the other hand, the latter standpoint is based on efforts to influence public affairs.

The partial goal of the article is to analyse e-participation as one of the key factors of the reinforcement of the current modernisation in public administration in post-communist countries which are mostly characterised by the participatory gap. It means that the focus is on the countries with a reduced participation in public affairs caused by the historical context, e.g. communist regime, centralised power and long absence of dialogue between the state and citizens before the Velvet Revolution in East Central Europe.

In that context, the hypothesis is based on the precondition that the e-participatory gap is also caused by the apathy of modern forms of political activism in post-communist countries.

1 Mgr. Veronika Džatková, PhD, Department of Public Policy and Theory of Public Administration, Faculty of Public Administration, Pavol Jozef Šafárik University in Košice, Popradská 66, 04132 Košice, Slovak Republic. 
After that the article is divided into three closely linked sections. The first one uses historical and descriptive methods which help analyse the term civil society from the various points of philosophical views. It deals with the long-lasting examination of civil society by such philosophers as John Locke or David Hume while simultaneously using the comparative method to put it side by side with current definitions of civil society and the increasing presence of the phenomenon of civil society in recent years.

The theoretical background of the term in question is directly linked to the second part of the article which focuses on the increasing role of civic participation in representative democracy. Its conclusions are related to empowering citizens in their role as decision-making actors at all levels.

The final part focuses on the current perspectives and limits of e-participation in post-communist countries. The article compares one of the most important pros and cons of e-participation and highlights the importance of further discussion and open questions about the future of e-participation in public administration.

\section{The phenomenon of civil society}

These days, the political-scientific aspect of civil society is examined more frequently. The reason for it is increasing opportunities and alternatives as regards the development of political participation and civic activism as well as pursuing the goal to be effective involved in different stages of the decision-making processes.

Although civil society as an object of exploration is highly topical, it has been practised for long. Philosophers like John Locke and Thomas Hobbes emphasised the role of the human being in civil society with the aim to empower people and bring the decision making process closer to them ${ }^{2}$. According to Karl Popper, open society created a vital part of democratic society ${ }^{3}$. The importance of active civil society has been analysed by Alexis de Tocqueville who focused his attention on various forms of participation in clusters, organisations and associations in the United States of America. ${ }^{4}$ This fact is still recognised in American society and, moreover, the country has still the highest percentage of participating citizens. Taking it into consideration, one can say that the historical and political development of civil society in the USA created a fertile ground for its current position. Diana Day said that participation in public affairs seemed to hold a sacrosanct position in the American political culture. It

\footnotetext{
2 H.J. Storig, Malé dejiny filosofie, Karmelitánske nakladatelství, Prague 2007.

3 K. Popper, The Open Society and Its Enemies, Princeton University Press 2013.

4 A. Tocqueville, Democracy in America, Penguin Classics, New York 2003.
} 
explains the differences between the European and American development of civil society ${ }^{5}$.

The initial level of civil society development was quite different in European countries. Every historical decade brought some political changes and different forms and positions of civil society in continental Europe. The increasing and decreasing scope of democratic principles has been accompanied by the existence or non-existence of effective civil society. The analogy between democracy and a functioning civil society could be explained by a quantitative model (more participating people lead to more legitimate decisions) and a qualitative model (more opportunities for people lead to a more democratic system) of political participation ${ }^{6}$. Despite the existence of many standpoints, we tend be inclined to the conclusion that the scope of democracy is directly related to the position of civil society.

It is necessary to say at this point that for political science and some of political scientists the two-way relation between civil society and democracy is disputable. Peter Kulašik says that democracy should be open and that it should be an opportunity for the citizen to participate in the political process. In that way, he demonstrates the level of democracy in a particular political system. Yet if the system is reluctant, if the requirements for increased participation of the ordinary citizen present a threat in some way, than it becomes undemocratic.

The renewal of civil society dates back to the Velvet Revolution and the end of communist regime in East Central Europe. Citizens in these countries started to use the opportunity to participate in various discussions and debates about democracy. In the words of Thomas Pain, civil society includes the right to be active for every citizen ${ }^{7}$. Civil society has started to promote the empowerment of common needs. According to Gaush Pasha, it helps active citizens with common interests and values to gain strength for cooperation and joint effort ${ }^{8}$.

Due to the changing forms of civil society which are a consequence of changes in the social and political situation, there is a wide variety of civil society definitions and platforms which could be examined from various points of view. For the purpose of this paper, the most important are the aforementioned political-scientific and public-policy standpoints.

5 D. Day, Citizen Participation in the Planning Process: An Essentially Contested Concept?, "Journal of Planning Literature" 1997, p. 421-434.

6 F. Briška, Teória a prax verejnej politiky, Bratia Sabovci, Zvolen 2010.

7 T. Paine, Rights of Man, H.O. Symonds, London 1792.

8 A. Ghaus Pasha, Role of civil society organizations in governance, 6th Global Forum on Reinventing Government Towards Participatory and Transparent Governance 24-27 May 2005, Seoul 2005, http://unpan1.un.org/intradoc/groups/public/documents/un/unpan019594.pdf (10.09.2016). 
Sara M. Evans and Herry C. Boyte define civil society as a public space which provides a great opportunity for participation in different debates and discussions about democracy ${ }^{9}$. In that context, it is necessary to have in mind the importance of the ethical aspect of public interest. "The code of conduct is the right step, which must be followed by some other actions. These should lead to the development of appropriate professional virtues of government employees and the overall ethical culture with an emphasis on the fulfilment of the obligations and pursue the public interest" ${ }^{\prime \prime}$. An effective and functioning civil society allows citizens to strengthen democratic conditions on various levels via influence on the actors of the decision-making process and active participation in public affairs. In other words, it helps to establish the conditions for supporting the acquired rights of all citizens to their further development.

"On the other hand, officials with qualities and values such as being responsive to the community needs, willing to listen and not only giving orders, and accepting the general public's participation in the governance of public affairs at all levels assure the people that those officials and representatives are responsible and accountable, as well as ready to serve them and improve the quality of their lives"11.

The aforementioned statements, confirm that the characteristics of an effective civil society such as pluralism, cooperation, separation of the state and market are completed by civic participation and political activism. "Domination and sovereignty of people is evident primarily by means of the use of political pluralism, the free choice of their representatives, execution of direct democracy, and the real implementation of measures which follow the principle of upholding the law"12. It necessitates further examination of the position of political participation in the democratic system.

\section{The increasing role of political participation in representative democracy}

Active civic participation in public affairs is one of the essential components in the democratic decision-making process on all levels and it seems that this is unlikely to change in the near future ${ }^{13}$. The reason is that

9 S.M. Evans, H.C. Boyte, Free spaces: the sources of democratic change in America, University of Chicago Press, Chicago 1992.

10 O. Mital, Etika vo verejnej správe v kontexte uplatňovania etických kódexov, "Verejná správa a spoločnost" 2016, Vol. 17, Iss. 1, p. 56-66.

11 D. Ondrová, Appeal for Ethical Accountability in Public Administration, "Rocznik Administracji Publicznej", Cracow 2016, p. 406.

$12 \mathrm{~J}$. Ondrová, Constitutional Adjustment of the Whole-National Referendum in the Slovak Republic, "Politické vedy" Roč. 13, č. 2, 2010, p. 120-129.

13 G.M. Higgins, J.J. Richardson, Political Participation, The Politics Association, London 1976. 
the increasing role of citizens in the decision-making process is also very important for current political and administrative authorities.

Moreover, the role of civic participation is based on the manner of implementing the participation process as a transformative tool for social change ${ }^{14}$.

It is now necessary to mention the existence of some statements with a negative image of participation and its impact on democratic systems. It results from historical events because in some cases active citizenship and civic participation in the decision-making processes was associated with an undemocratic regime. In the words of Robert Dahl, civic participation helped create an "abominable system". The increasing engagement of citizens has been also associated with scepticism. The position of authorities was threatened by their subordinates. The negative consequences of civic activism also included various forms of extensive civic organisations in Italy and Spain whose activities helped to spread anti-democratic forms of government such as fascism and authoritarianism. It used to be called uncivil civil society ${ }^{15}$.

Consequently, the increasing role of civic participation is multiplied by other factors e.g. globalisation and Europeanisation which create trends for a higher number of political actors and forms of political participation as well. In the European Commission's White Paper, it is explicitly expressed that political participation is an essential part of the decision-making processes in the countries of the European Union.

The new model of ruling-governance also promotes civic engagement in public affairs, supports democratic institutions and focuses on processes and impacts of the third sector in the decision-making process ${ }^{16}$. Governance deals with a new wide scale of political institutions, forms of cooperation between the private and public sectors, civil society and forms of transnational cooperation, etc. ${ }^{17}$

Ralf Dahrendorf highlights the fact that the rise of the notion of governance is based on the current crisis of the traditional concept of government characterised by the loss of trust in elected representatives who promote

14 N. Nelson, S. Wright, Power and Participatory Development: Theory and Practice, Intermediate Technology Publications, London 1995.

15 R. Dahl, Demokracie a jej kritici, Victoria Publishing, Prague 1995.

16 P. Vymětal, Proměny teoretických koncepcí governance [in:] III. Kongres českých politologů. Česká společnost pro politické vědy, Prague 2006.

17 M. Potůček, Strategic Governance in Central and Eastern Europe: From Concepts to Reality, a paper submitted to the 14th NISPAcee Annual Conference 2006 or "Educational Leadership and Management Studies", http://www.nispa.org/ conf_paper_detail.php?cid=14\&p=571\&pid=1169 (18 September 2016). 
interests of selected economic groups instead of those of citizens ${ }^{18}$. In other words, we are talking about the crisis of democracy ${ }^{19}$.

Finally, it must be said that active citizenship and political participation could be a panacea for crisis in representative democracy and it also has a potential to overcome obstacles related to it. Political participation fills the vacuum between the state and citizens and strengthens trust in public institutions.

\section{Perspectives and limits of e-participation}

The increased interest in civil society is related to the current social and political situation which is related to the aforementioned crisis of representative democracy, more specifically with the deficit of political participation at local, regional or national levels. In this context, it is necessary to ask the following question: How can citizens participate? Today, digital technologies make it possible to have massive citizen participation in policy making and political processes. The huge influence of ICT is felt in public administration, too. After all, representatives of civil society could, with the help of ICT, create a background for empowering political participation and civic activism with the aim to have an impact on the public policy actors and make decision-making processes more effectual.

E-participation could be considered a multidimensional term associated with different fields. For our purposes, the most important is the political scientific point of view, in general associated with democratic principles ${ }^{20}$. It means that it ensures the communication and information aspect of democracy which is directly linked to distributing information e.g. via e-participation.

Attempts to overcome the participatory deficit are one of the reasons for empowering civil society mainly via the strengthening of the relationship between the citizen and the state. This entails various forms of public gatherings, discussions with political representatives and experts, debates and consultations provided by means of ICT. E-participation enables the fastest way to spread thoughts and ideas between individuals, groups and third parties in various decision-making processes in public policy.

The e-participation framework consists of information, consultation and decision-making. The importance of the first stage has been emphasised also by Robert Dahl and his concept of ideal democracy where

18 R. Dahrendorf, Class and Class Conflict in Industrial Society, Stanford University Press, Stanford 1959.

19 J. Habermas, Legitimation Crisis, Beacon Press, Boston 1975; Ch. Mouffe, The Democratic Paradox, Verso, London 2000; C. Crouch, Post-Democracy, Polity Press, Cambridge 2004.

20 D. Špaček, E-government: cíle, trendy a př́stupt k jeho hodnocení, C.H. Beck, Praha 2012. 
he highlighted the necessity of providing adequate information to citizens at all stages of the decision-making process ${ }^{21}$.

Contemporary authors consider e-participation as a part of e-democracy (Macintosh, Whyte 2002, Clift 2004) while others as a separate category of e-government (Westhall, Wimmer 2007) ${ }^{22}$.

Selected e-participation tools by Thorleifsdottir and Wimmer:

- e-consultation

- online office hours

- e-petition

- discussion forums

- blogs

- e-panel discussion

- e-polling

- chat rooms ${ }^{23}$.

All of these mentioned tools:

1. Improve the citizen's access to information and public services.

2. Promote participation in public decision-making which impacts the well-being of society.

3. Intend to help make better decisions and thus ensure more efficiency benefits for the rest of society.

As regards the current state of distrust, suspicion and fears of citizens related to modernisation processes, it is necessary to highlight the pros and cons of e-participation in public policy.

Benefits of e-participation:

- allows a wider audience to contribute to the democratic debate,

- supports participation through a range of technologies to utilise citizens' diverse technical and communicative skills,

- provides relevant information in a format that is both more accessible and more understandable to the target audience,

- supports the state-citizen relationship,

- provides feedback, so citizens are heard,

- enables, engages and empowers civil society,

- builds a bridge between citizens and the state.

Limits of e-participation:

- participatory gap - caused by centralised power and long-lasting absence of any kind of political participation, which was typical for post-communist countries in East Central Europe,

- time gap in the adoption of new digital technologies in the public sector,

- old structures and practices which still prevail in most institutions, services and policy-making processes,

- current state of distrust, suspicion and fear felt by citizens,

21 R. Dahl, Demokracie a jej kritici, Victoria Publishing, Prague 1995.

22 D. Špaček, E-government: cíle, trendy a př́stupt k jeho hodnocení, C.H. Beck, Prague 2012.

23 A. Thorleifsdottir, M. Wimmer, Report on current ICTs to enable Participation, DEMO-net: Deliverable 5.1, http://www.demo-net.org/what-is-it-about/ research-papers-reports-1/demo-net-deliverables/pdfs/DEMO-net_D5.1.pdf/ (15 January 2015). 
- the problem of getting involved in public affairs quickly and efficiently as regards language and manner,

- online activism providing a space for the expression of hate and xenophobic behaviour.

\section{Conclusion}

Francis Fukuyama said about civil society that it was something that the state can more easily destroy than establish ${ }^{24}$. The importance of this statement still persists. One of the manners in how to empower civil society is to promote modern forms of participation.

The preliminary hypothesis has been proved. Theoretical research has confirmed that the e-participation had the potential to overcome obstacles related to the participatory gap in post-communist societies and on the basis of the aforementioned perspectives it presents one of the tools for social change.

The potential of e-participation is multiplied in the countries characterised by the participatory gap, e.g. in East Central Europe.

Finally, we can say that it is necessary to emphasise that e-participation has the prospective to be one of the key tools to overcome obstacles related to the participatory deficit in the near future. Yet there are two standpoints to evaluate its efficiency.

On the one hand, the generation born in post-communist countries is politically active but has a negative or, in other words, deliberate attitude to ICT.

On the other hand, there are millennials, who have the required knowledge and understanding of modern gadgets and technology but, with some exceptions, do not use it for political or participatory purposes.

That is the main reason why it is so important to deal with the generation factor in post-communist countries which disturbs the balance and makes the quest for progress highly urgent.

\section{Bibliography}

Briška F., Teória a prax verejnej politiky, Bratia Sabovci, Zvolen 2010.

Crouch C., Post-Democracy, Polity Press, Cambridge 2004.

Dahl R., Demokracie a jej kritici, Victoria Publishing, Praha 1995.

Day D., Citizen Participation in the Planning Process: An Essentially Contested Concept?, "Journal of Planning Literature" 1997.

Dahrendorf R., Class and Class Conflict in Industrial Society, Stanford University Press, Stanford 1959.

24 F. Fukuyama, The End of History and the Last Man, The Free Press, New York 2006. 
Evans S.M., Boyte H.C., Free spaces: the sources of democratic change in America, University of Chicago Press, Chicago 1992.

Ghaus Pasha A., Role of civil society organizations in governance, 6th Global Forum on Reinventing Government Towards Participatory and Transparent Governance 24-27 May 2005, Seoul 2005, http://unpan1.un.org/intradoc/groups/ public/documents/un/unpan019594.pdf.

Fukuyama F., The End of History and the Last Man, The Free Press, New York 2006.

Habermas J., Legitimation Crisis, Beacon Press, Boston 1975.

Higgins G.M., Richardson J.J., Political Participation, The Politics Association, London 1976.

Kulašik P., Politológia, Efekt copy, spol.s.r.o., Hlohovec 2005.

Mital' O., Etika vo verejnej správe v kontexte uplatňovania etických kódexov, "Verejná správa a spoločnost" 2016, Vol. 17, Iss. 1.

Mouffe Ch., The Democratic Paradox, Verso, London 2000.

Nelson N., Wright S., Power and Participatory Development: Theory and Practice, Intermediate Technology Publications, London 1995.

Ondrová D., Appeal for Ethical Accountability in Public Administration, "Rocznik Administracji Publicznej", Cracow 2016.

Ondrová J., Constitutional Adjustment of the Whole-National Referendum in the Slovak Republic, "Politické vedy" Roč. 13, č. 2, 2010.

Paine T., Rights of Man, H.O. Symonds, London 1792.

Popper K., The Open Society and its Enemies, Princeton University Press 2013.

Potůček M., Strategic Governance in Central and Eastern Europe: From Concepts to Reality, a paper submitted to the 14th NISPAcee Annual Conference 2006 or "Educational Leadership and Management Studies", http://www.nispa.org/ conf_paper_detail.php?cid=14\&p=571\&pid=1169.

Putman R.D., Bowling Alone: The Collapse and Revival of American Community, Simon and Schuster Paperbacks, New York 2000.

Storig H.J., Malé dejiny filosofie, Karmelitánske nakladatelství, Prague 2007.

Špaček D., E-government: cíle, trendy a přistupt $k$ jeho hodnocení, C.H. Beck, Prague 2012.

Thorleifsdottir A., Wimmer M., Report on current ICTs to enable Participation, DEMO-net: Deliverable 5.1., http://www.demo-net.org/what-is-it-about/research-papers-reports-1/demo-net-deliverables/pdfs/DEMO-net_D5.1.pdf/.

Tocqueville A., Democracy in America, Penguin Classics, New York 2003.

Vymětal P., Proměny teoretických koncepcí governance [in:] III. Kongres českých politologů. Česká společnost pro politické vědy, Prague 2006.

Abstract

Besides other aspects, one of the fundamental conditions of the modern political system is active and powerful civil society. Representatives of civil society and their increasing influence provide the background for increasing political participation and civic activism with the aim to make decision-making processes more effectual and having an impact on public policy actors. In that context, the objective of the article is to 
pay particular attention to one of the forms of participation, specifically using a comparative method to theoretically analyse the perspectives and limits of e-participation. The paper presumes the inevitable role of e-participation in the current modernisation of public administration processes which could overcome obstacles related to the participatory gap in post-communist countries.

Keywords: civil society, representative democracy, political participation, e-participation, participatory gap

\section{E-uczestnictwo w procesie decyzyjnym w krajach postkomunistycznych}

Streszczenie

Jednym z kluczowych warunków nowoczesnego systemu politycznego jest aktywne i silne społeczeństwo obywatelskie. Rosnący wpływ jego przedstawicieli i uczestnictwo wielu osób w życiu politycznym zwiększają aktywizm społeczny, dzięki któremu procesy decyzyjne mogą być wydajniejsze i wpływać na podmioty polityk publicznych. Celem artykułu jest zwrócenie szczególnej uwagi na e-partycypację, jako jedną z form uczestnictwa, przy zastosowaniu metody porównawczej do teoretycznej analizy jej perspektyw oraz ograniczeń. Autorka sądzi, iż e-partycypacja będzie odgrywać coraz większą rolę w obecnej modernizacji procesów zachodzących w administracji publicznej, które mogą wpłynąć na pokonanie przeszkód związanych z luką partycypacyjną w krajach postkomunistycznych.

Słowa kluczowe: społeczeństwo obywatelskie, demokracja przedstawicielska, uczestnictwo polityczne, e-uczestnictwo, luka partycypacyjna 